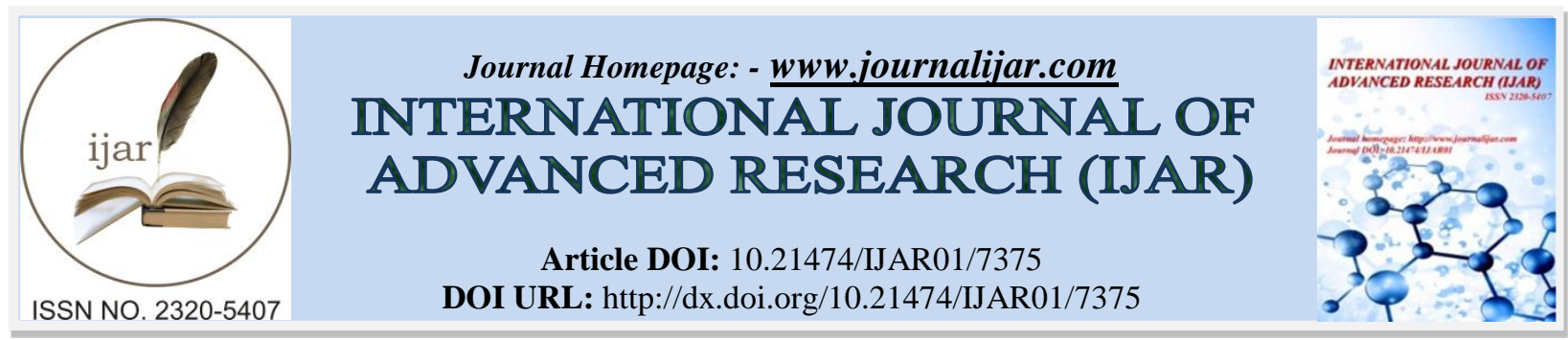

RESEARCH ARTICLE

\title{
THE CONSISTENCY OF LEGAL ANALYSIS FOR DOCUMENT PLANNING AND IMPLEMENTATION OF RURAL FINANCIAL MANAGEMENT BASED ON WORK PROGRAM IN REGENT OF NORTH BOLAANG MONGONDOW.
}

Dina Novitasardi Katong ${ }^{1}$, Abdul Razak ${ }^{2}$ and Marwati Riza ${ }^{3}$.

1. Graduate School, Faculty of Law, Hasanuddin University.

2. Faculty of Law, Hasanuddin University.

\section{Manuscript Info}

Manuscript History

Received: 09 May 2018

Final Accepted: 11 June 2018

Published: July 2018

Keywords:-

Consistency, Legal Analysis, Rural

Financial Management, Work Program.

\begin{abstract}
In Law Number 6 of 2014 article 81 paragraph (1) it is explained that the Village Development is carried out in accordance with the Village Government Work Plan. From the explanation of those articles shows that, development done in the Village must be done in accordance with the planning that has been in the previous arrangement, it is intended that development planning and implementation are integrated. The preparation of this work plan helps the village government in the implementation stage of the activity, so that the activities carried out can provide benefits for the village community. In the village development planning process, the village government should prepare three (3) planning documents namely the Village Mid Term Development Plan, the Village Government Work Plan, and the Village Revenue and Expenditure Budget. In accordance with the data that researchers have obtained several villages in Bolaang Mongondow North District in making the development planning documents of the village always reap various technical problems. So that impact on the process of realization of the implementation.
\end{abstract}

Copy Right, IJAR, 2018,. All rights reserved.

\section{Introduction:-}

The essence of development planning is an activity in determining the direction of the policy in accordance with the needs of the community with a variety of methods and the flow of systematic activities by looking at the quality of resources owned. Planning is a continuous process, which consists of decisions or choices and various ways to use existing resources, with the goal of achieving certain goals in the future. Basically, all development activities will only be directed when based on a development plan and controlled, and evaluated.

Planning is basically a means, technique or method to achieve the desired objectives precisely, directed and efficient in accordance with the available resources. Thus development planning is a way or technique to achieve the development goals accurately, directed, and efficiently in accordance with the conditions of the country or region concerned. While the purpose of development in general is to encourage the development process more quickly in order to realize a society that is advanced and prosperous. ${ }^{1}$

\footnotetext{
${ }^{1}$ Sjafrizal, Perencanaan Pembangunan Daerah dalam era Otonomi, Rajawali Pres, Jakarta, 2015, p. 24
}

Corresponding Author:- Dina Novitasardi Katong.

Address:- Graduate School, Faculty of Law, Hasanuddin University. 
The Birth of the Village Law assures the Village that each village will receive funds from the government through large amounts of state and regional budgets, well above the amount already available in the village budget. One of the funds raised by the central government from the State Revenues and Expenditure Budgets is the Village Fund which starts from 2015, by 2017 the Government allocates the Village Fund of approximately 60 Trillion for 74,954 Villages spread all over Indonesia. ${ }^{2}$ In addition to the Village Fund, village finances are also sourced from the Village's Original Income and other Transfer Income in the form of Village Fund Allocation, Part of District and City Taxes and Levies, Financial Assistance from Provincial/District/City Revenue and Expenditure Budget, and/or grants and non-binding third-party contributions and other legitimate village income.

This policy has consequences for its management processes that must be implemented professionally, effectively and efficiently, and accountable on the basis of sound financial management principles to avoid the risk of deviation, misuse and corruption.

Under the general provision of article 1, paragraph (6), the Minister of Home Affairs Regulation Number 113 of 2014 the management of village finance is the whole activity which includes planning, implementation, administration, reporting, and accountability of village finances. ${ }^{3}$

In exercising village development authority, village governments have a duty in planning, budgeting and carrying out development or service activities, as well as solving emerging problems.

Planning is a basic requirement for village financial management. Therefore, as the organizer, the village government is obliged to provide planning documents in managing the village finances. Just as national and regional development planning at the village level should also provide three important types of documents: the Village Medium Term Plan, the Village Government Work Plan and the Village Revenue and Expenditure Budget, without these three village administrations will not be able to manage the village finances properly.

In Law Number 6 of 2014 article 81 paragraph (1) it is explained that the Village Development is carried out in accordance with the Village Government Work Plan. ${ }^{4}$ From the explanation of the articles above shows that, development done in the Village must be done in accordance with the planning that has been in the previous arrangement, it is intended that development planning and implementation are integrated. The preparation of this work plan helps the village government in the implementation stage of the activity, so that the activities carried out can provide benefits to the village community. The success of village development can be seen from the good development of village development and the implementation of the planned cathedral program. Vice versa if in the implementation of the deviation then it will be bad for the achievement of village development that is not in accordance with the purpose of law is the welfare of the community, such as cases that occurred in North Bolaang Mongondow District North Sulawesi Province.

Based on the complaints data obtained by the authors in the complaint form related to the problems of village development implementation and managerial problems in Bolaang Mongondow North District as follows: ${ }^{5}$

\begin{tabular}{|c|c|c|c|c|}
\hline Reporter & Problem & $\begin{array}{c}\text { Problem } \\
\text { Perpetrator }\end{array}$ & Districts & Village \\
\hline Society & $\begin{array}{c}\text { There is an indication of } \\
\text { corruption of misuse of the } \\
\text { Village Fund about the } \\
\text { proposal of cattle }\end{array}$ & $\begin{array}{c}\text { Village Head and } \\
\text { Activity } \\
\text { Management } \\
\text { Team }\end{array}$ & Bintauna & Padang \\
\hline Society & $\begin{array}{c}\text { The existence of an activity } \\
\text { program that is not } \\
\text { implemented }\end{array}$ & $\begin{array}{c}\text { Village } \\
\text { government }\end{array}$ & Bintauna & Padang \\
\hline
\end{tabular}

${ }^{2}$ BPK, Sinergi Pengawasan Untuk Percepatan Pembangunan Yang Akuntabel, Warta Pengawasan, Vol XXIV No 2, 2017 , p. 5

${ }^{3}$ Article 1 paragraph 6 of the Minister of Home Affairs Regulation No. 113 of 2014

${ }_{5}^{4}$ Article 81 paragraph (1) of Law Number 6 Year 2014 on the Village

5 Team of Experts Program for Development and Empowerment of Village Community of Village Ministry of North Sulawesi Province 


\begin{tabular}{|c|c|c|c|c|}
\hline Society & $\begin{array}{l}\text { Work Load is charged to the } \\
\text { public }\end{array}$ & $\begin{array}{c}\text { Village } \\
\text { government }\end{array}$ & East Biolangitang & Soligir \\
\hline $\begin{array}{l}\text { Village } \\
\text { counselor }\end{array}$ & $\begin{array}{l}\text { The installation of solar lights } \\
\text { using the Village Fund, and } \\
\text { the village bintauna beach } \\
\text { using electricity State Electric } \\
\text { Company }\end{array}$ & village secretary & Bintauna & Bintauana Pantai \\
\hline Society & $\begin{array}{l}\text { The process of conducting the } \\
\text { activity is done in pre- } \\
\text { implementation meeting stage }\end{array}$ & $\begin{array}{c}\text { Village } \\
\text { government }\end{array}$ & Bolaangitang & Bolaangitang \\
\hline $\begin{array}{l}\text { Village } \\
\text { counselor }\end{array}$ & $\begin{array}{l}\text { The proposed activities have } \\
\text { not been in accordance with } \\
\text { the priority objectives of } \\
\text { village development }\end{array}$ & $\begin{array}{c}\text { Village } \\
\text { government }\end{array}$ & Bolaangitang & Telaga \\
\hline
\end{tabular}

From the above data it can be seen that in 2017 there were 7 complaints from the community, and the village counterpart team. The complaint is suspected to be a problem in the implementation of a work program that is inconsistent with the planning and the perpetrator of the problem is the village government itself. Village administration should be more concerned about the use of funds that not only prioritize personal gain but its usefulness for the people who must be the main goal.

Based on the problems that occur the authors suspect that the village government in managing village finance doesn't pay attention to the priority programs that become the needs of the community, the village development planning document made only focus on the formalities just as a condition for disbursement of the budget, so that when the implementation there are many deviations. In addition, the allocation of Village Funds managed in large numbers whose purpose for the development of the Village is feared there is fraud so that in the implementation of it often occurs the reduction of volume and mark up of the budget, of course this action is an action that leads to corruption. This has caused the inconsistency of village government in implementing the planned work program. Based on the above background description, the authors will analyze the related consistency of village financial management planning in its implementation in terms of conformity of one year budget work program in North Bolaang Mongondow district.

\section{Method of the Research:-}

Research is a scientific activity related to analysis and construction, which is done methodologically, systematically and consistently. Methodological means in accordance with a method or a particular way, systematic is based on a system, while consistent means the absence of contradictory things within a certain framework. ${ }^{6}$ This research uses empirical juridical research. Empirical juridical research is by conducting field research by looking at the reality and doing direct interviews and see the facts that exist in the field of village financial management, especially in the planning and implementation stage.

In conducting the research, the writer took the research location in Bolaang Mongondow District by collecting the data in several places, the Bolaang Mongondow Village Community Empowerment Office, the Financial and Development Supervisory Board of Bolaang Mongondow District and the Bolaang Mongondow County Inspectorate and several Villages in Bolaang Mongondow District which in the management of financial deviations occur. The selection of sites is based on the consideration that some villages in Bolaang Mongondow District indicate problems in village financial management.

\section{Results and Discussion:-}

Consistency of Village Development Planning and Implementation in Bolaang Mongondow North District Stages of Village Development Planning in Bolaang Mongondow North District

\footnotetext{
${ }^{6}$ Soerjono Soekanto, Pengantar Penelitian Hukum, Jakarta, 2015, .p 42
} 


\section{Stages of Preparation of Medium Term Development Plan of Villages In Bolaang Mongondow North District:-}

The Medium Term Development Plan of the Village shall be established for a maximum period of 3 (three) months from the time of the inauguration of the Village Head. The Medium-Term Development Plan of the Village contains the vision and mission of the village head, the direction of the village development policy, and the activity plan which includes the field of village governance, the implementation of the village development, the village community development and the empowerment of the village community. ${ }^{7}$

The process of organizing the village development planning in Kabupaten Bolaang Mongondow North, from the results of the interview with the researcher Mr. Samuel Pontoh, the Village Planning Officer on March 7, 2018. "Overall it has been in accordance with the mechanisms mandated by the law that the village government has involved elements of the village community as part of planning what programs will be proposed, but for the determination of the village mid-term development plan of most villages in the district of North Bolaang Mongondow is slow, since there are several villages where the Village Mid-term Development Plan is set after the following year" ${ }^{8}$ This is also similar to the data obtained by researchers in 18 villages that became sample research that is

Table 4.1:-Sources of research in 18 villages of North Bolaang Mongondow District

\begin{tabular}{|l|c|c|c|c|}
\hline No & Village Name & Districts & Date of Inauguration & Determination Date \\
\hline 1. & Dengi & Pinogaluman & $24-12-2015$ & $05-05-2016$ \\
\hline 2. & Tontulaw & Pinogaluman & $26-01-2016$ & $28-11-2016$ \\
\hline 3. & Buko & Pinogaluman & $28-10-2014$ & $28-12-2015$ \\
\hline 4. & Bolangitang & West Bolangitang & $16-12-2015$ & $16-01-2016$ \\
\hline 5. & Bolangitang 1 & West Bolangitang & $24-12-2014$ & $28-12-2015$ \\
\hline 6. & Iyok & West Bolangitang & $20-12-2015$ & $25-12-2015$ \\
\hline 7. & Bunia & Bintauna & $10-03-2015$ & $30-01-2016$ \\
\hline 8. & Nagara & East Bolangitang & $22-10-2015$ & $07-12-2015$ \\
\hline 9. & Biontong & East Bolangitang & $11-11-2014$ & $01-01-2016$ \\
\hline 10 & Binuanga & East Bolangitang & $01-05-2015$ & $05-01-2016$ \\
\hline 11. & Soligir & Kaidipang & $01-012017$ & $01-01-2017$ \\
\hline 12 & Busisingo North & Sangkub & $31-12-2015$ & $31-12-2015$ \\
\hline
\end{tabular}

From the above data it can be seen that the whole village which is the sample of the research is not timely in determining the Medium Term Development Plan of the Village. From 18 villages, the sample was only 6 villages in time to determine the Medium Term Development Plan of the Village, which is three months after the Village Head's pelantkan. The lack of human resources in village governance in formulating what programs will be incorporated into the Medium Term Development Plan document of the village as the basis of the planning reference for the next 5 years based on the existing conditions in the village is a matter of delay in the preparation of the document The Medium Term Development Plan Villages, village governments have difficulty in terms of synchronization of district development programs with work programs to be made in the Village. The results of interviews with the Head of Binuanga Village on July 2 2018, that is "Obstacles encountered in the preparation of the Planning Document, such as the Medium-Term Development Plan document of the Village Government is not yet fully capable in designing a plan containing the planning based on the direction of local government policy as well as the condition of the Village, especially as a reference for the next 5 years." $"$

The village of Binuanga is a late village in establishing the Village Rules of the Village Medium Term Development Plan, which should be set in August 2015 but in reality the Village Regulation on the Village Mid Term Development Plan for Binuanga Village is set in January 2016. Preparation of village development planning should

\footnotetext{
${ }^{7}$ Article 5-9 of Law Number 6 Year 2014 on the Village

${ }^{8}$ Samuel Pontoh. Staff of the Village Community Empowerment Service of Bolaang Mongondow North District. On March 7, 2018

${ }^{9}$ Sunarto Van Gobel. Head of Binuanga Village, East Bolangitang Sub-district, Bolaang Mongondow North District. July 2, 2018. Binuanga Village
} 
be really based on community interests. Includes all circles, so that the planned development can be really felt by the community.

\section{Stages of Preparation of the Village Government Work Plan in North Bolaang Mongondow District:-}

The Village Government in making the Working Document of the Village Government should take account of the existing programs in the Village Mid-term Development Plan as a basis for formulating the village's annual program that contains the programs that the village needs. The Village Government Work Plan is in shape and in keeping with the Village Rules and becomes the basis for establishing the Village Revenue and Expenditure Budget. The Village Government Work Plan is an annual planning document Village and Revenue and Expenditure Budget is a Village Budget Document in the Budget Year.

The Village Government in the northern Bolaang Mongondow District in preparing the document of the Village Government Work Plan has been in accordance with the technical implementation, the district government in this case the Village Community Empowerment Office and the Village Counseling Professionals who always coordinate with the village government related to the problems encountered in the preparation of the Work Plan Village government. However, in the time of drafting and determining the village government is not in accordance with the timing of the Village Government Work Plan should begin to be prepared by the Village Government in July of the current year and must be set no later than in September of the current budget year. In accordance with the data obtained by the researchers in the field can be seen all villages that become the sample of this study is not timely in the determination of the Government Work Plan yatu no later than September of the current year.

Table 4.3:- Sources of Research Data In 18 Villages North Bolaang Mongondow District

\begin{tabular}{|l|l|l|}
\hline Village Name & \multicolumn{1}{|c|}{ districts } & Determination Date \\
\hline Dengi & Pinogaluman & November 22, 2016 \\
\hline Tontulaw & Pinogaluman & November 28, 2016 \\
\hline Buko & Pinogaluman & January 29, 2016 \\
\hline Bolangitang & Bolangitang Barat & January 27, 2016 \\
\hline Bolangitang 1 & Bolangitang Barat & January 29, 2016 \\
\hline Iyok & Bolangitang Barat & March 4, 2016 \\
\hline Bunia & Bintauna & January 30, 2016 \\
\hline Nagara & Bolangitang Timur & February 22, 2016 \\
\hline Biontong & Bolangitang Timur & March 8, 2016 \\
\hline Binuanga & Bolangitang Timur & January 5, 2016 \\
\hline Soligir & Kaidipang & January 24, 2016 \\
\hline Busising North & Sangkub & January 30, 2016 \\
\hline
\end{tabular}

Based on Table 4.3 above, it can be seen that 18 villages in Bolaang Mongondow North District in 6 subdistricts don't meet the stipulation time set in the Minister of Home Affairs Regulation Number 114 Year 2014 About Rural Development. This is because the village government has a delay in the process of implementing the village meetings, so the process of deliberation of the village meeting is too much so that it impacts on the date of its determination.

In accordance with the results of interviews with researchers of the Village Community Empowerment Office of Bolaang Mongondow North District, Mr. Samuel Pontoh on March 7, 2018: "Villages that have delay in stipulating the Village Government Working Plan are due to the usual time of village deliberation which should be finished in July, but usually takes more time than specified, because there is no agreement for what priority programs will be made for in the subsequent years, considering that the existing funds don't adequately accommodate all the program proposals from each hamlet, and usually the village also postponed the timing of the Village Deliberation so that resulted in the timing of the determination". 10

The Village Government Work Plan is a planning document for 1 Year budget which will be the guideline in budgeting which is set forth in the Village Revenue and Expenditure Budget. The delay in determining the Village

\footnotetext{
${ }^{10}$ Samuel Pontoh. Staff of the Village Community Empowerment Service of Bolaang Mongondow North District. On March 7, 2018
} 
Revenue and Expenditure Budget will have an impact on the determination of the Village Revenue and Expense Budget that must be set by December 31 of the current year. Therefore, the village government is expected to accelerate the formulation of work programs that will be contained in the Working Document of the Village Government. From the data table above visible stipulation of Village Government Rural Government Work Plan in all villages that become the sample research set in January and February which should in December has been included in the agenda Stipulation of Village Rules Revenue and Expenditure Budget. So this has an impact on the delay in determining the Village Revenue and Expenditure Budget.

c). Stages of Preparation of Village Revenue and Expenditure Budget in Bolaang Mongondow North District In practice, a good plan will be useful if offset by the provision of resources, including adequate budgets. Budgeting is an important element that supports planning and implementation. But even more important is to maintain continuity in the planning process and budgeting synergistically in one workflow. Simply plan must be supported by budget and budget prepared by plan. ${ }^{11}$

The process of preparing the Village Revenue and Expenditure Budgets in Bolaang Mongondow North District has a delay at the time of establishment, the average village has a delay in its determination process which should be fixed on December 31 and submitted to the Bolaang Mongondow North Village Community Empowerment Agency as a procedure in the disbursement of the total budget already contained in the Village Revenue and Expenditure Budget but in reality the average Village in Bolaang Mongondow North district is not timely in its determination. This happens because of the delay of the village government in determining the Village Rural Working Rural Government Regulation which is a guideline in budgeting.

The following table is the time of setting the Budget of Revenue and Expenditure of villages that menajdi sample research:

\begin{tabular}{|c|c|c|c|}
\hline No & Village Name & Districts & Determination Date \\
\hline 1 & Dengi & Pinogaluman & May 10, 2017 \\
\hline 2 & Tontulaw & Pinogaluman & May 5, 2017 \\
\hline 3 & Buko North & Pinogaluman & May 2017 \\
\hline 4 & Bolangitang & West Bolangitang & May 13, 2017 \\
\hline 5 & Bolangitang 1 & West Bolangitang & May 12, 2017 \\
\hline 6 & Iyok & West Bolangitang & May 13, 2017 \\
\hline 7 & Bunia & Bintauna & May 10, 2017 \\
\hline 8 & Nagara & East Bolangitang & May 12, 2017 \\
\hline 9 & Boiontong & East Bolangitang & May 5, 2017 \\
\hline 10 & Binuanga & East Bolangitang & May 12, 2017 \\
\hline 11 & Bigo & Kaidipang & May 14, 2017 \\
\hline 12 & Soligir & Kaidipang & Sangkub \\
\hline 13 & Busisingo North & &
\end{tabular}

Table 4.4:-Sources Research that the authors obtain in the Village

From the above data it can be seen that all the villages in the study sample have a delay in establishing the Village Revenue and Expenditure Budget. This happens because of several factors, namely the lack of human resources of the village government in designing and formulating the Revenue and Expenditure Budget of the Village which contains details of the budget and the grapis design of village development programs in this case related to the development of infrastructure, and the existence of the central often changing, which resulted in the Village government having difficulties in the preparation of the Budget Document of Revenue and Expenditure of the Village. Based on the results of interviews that the authors do with some of the first speakers with the father of Samuel Pontoh employee Village Community Empowerment Village Bolaang Mongondow North district on March 7, 2018: "The average village government in making the Budget Document of Revenue and Expenditure Village has not really understood the existing rules, usually the village government rely on instant system copy paste from other villages where the Village Revenue and Expenditure Budget is completed or just copy paste from the Revenue

\footnotetext{
${ }^{11}$ Tim Penyusun Policy Paper, Sinergi Perencanaan dan Penganggaran, KPPN, Jakarta, 2015, p. 2
} 
Budget and The Village Fund and its priority programs There are so many mistakes in incorrect that the Village Community Empowerment Board always corrects the contained in the Village Revenues and Expenditure Documents, besides the obstacles in the drafting of the budget expenditure which is the detail of each budget program and program design that the village government finds difficult to design it". ${ }^{12}$

This is also the case when the researchers met while at the Village Community Empowerment Office of Bolaang Mongondow North District in March 2018, there are still many villages that have not completed the Revenue and Expenditure Budget of the Village. So the budget disbursement process was too late. The problem that the resource persons described above, is a common problem that often occurs in the village government, the availability of Human Resources is still very less. This is also justified by the Secretary of the Village Sangkub 1 District Sangkub Safrudin Hasan. "The problem often encountered in the development of the Revenue and Expenditure Budget document, the drawing design, because in the Village Revenue and Expenditure document it contains all the elements present in the program of activities, from the details of the budget for each program to its design drawings so that we little difficult to find it". ${ }^{13}$

Technical issues related to the drafting of the Expenditure Budget for the program of activities become the constraints of the village community because the Draft Expenditure Budget for itself contains the drawing of the program design activities and budget details of the costs and materials in detail from the Draft Expenditure Budget for which we can know the results of the achievements and the details of the budget required. Therefore, the village government is in need of experts in the field of infrastructure that controls the field, so that the Village Revenue and Expenditure Budget document made by the village government is not only made for the purpose as a condition in the disbursement of budget funds but the village government more attention to academic elements. So that the village government pay more attention to the process in making the Budget Document of Revenue and Expenditure Village not only prioritize the element of achieving the target alone.

The following table includes the income of the Village Revenue and Expenditure Budget document at the Village Community Empowerment Office of Bolaang Mongondow North Regency in the fiscal year 2016-2017.

\begin{tabular}{|c|c|c|c|}
\hline No & Village Name & Districts & Income Date \\
\hline 1 & Dengi & Pinogaluman & May 26, 2017 \\
\hline 2 & Tontulaw & Pinogaluman 19,2017 \\
\hline 3 & Buko North & Pinogaluman & May 20,2017 \\
\hline 4 & Bolangitang & West Bolangitang & May 15, 2017 \\
\hline 5 & Bolangitang 1 & West Bolangitang 16,2017 \\
\hline 6 & Iyok & West Bolangitang & May 31, 2017 \\
\hline 7 & Bunia & Bintauna 14,2017 \\
\hline 10 & Nagara & East Bolangitang & May 15,2017 \\
\hline 11 & Biontong & East Bolangitang 2,2017 \\
\hline 12 & Binuanga & East Bolangitang & June 19,2017 \\
\hline 13 & Bigo & Kaidipang 2,2017 \\
\hline 15 & Soligir & Kaidipang & May 23, 2017 \\
\hline 16 & Busisingo North & Sangkub & May 30, 2017 \\
\hline
\end{tabular}

Table 4.5:-Source of Bolaang Mongondow North Village Community Empowerment Office ${ }^{14}$

From the table above can be seen the delay in the inclusion of documents of the Village Revenue and Expenditure Budget at the Village Community Empowerment Office in South Bolaang Mongondow District which is an administrative requirement for fund disbursement. This has been a problem for the time of construction of infrastructure in the village. In Government Regulation Number 8 of 2016 on Village Funds sourced from the State Revenue and Expenditure Budget it is explained that: The distribution of village funds from the Regional General Treasury Account to the Government Work Plan is done after the Regent/mayor receives from the village head:

\footnotetext{
${ }^{12}$ Samuel Pontoh. Staff of the Village Community Empowerment Service of Bolaang Mongondow North District. On March 7, 2018

${ }^{13}$ Safrudin Hasan. Secretary of Sangkub Village 1. March 22, 2018. Sangkub Village Office 1

${ }^{14}$ Service of Village Community Empowerment. Planning Section. March 16, 2017
} 
1. Village Rules on Village Revenue and Expenditure Budget for the current fiscal year, and

2. Report on the realization of the use of the Village Fund the previous year. ${ }^{15}$

3. From the above explanation of the article can be seen that the Village Revenue and Expenditure Budget is one of the requirements that must be met by the village government in terms of disbursement of funds to finance the budget implementation of the program next year activities are conveyed to the Regent in this case through the Work Unit Regional, namely the Village Community Empowerment Office.

\section{Factors Affecting Inconsistency Between Planning and Budgeting. Regulation Of Central Government}

Regulatory factors from the central government that the researcher needs to improve such as the Village Minister's Regulation on Priority of Village Fund Usage which is often late, with the delay of this Village Minister Regulation, it is possible that the Village Government Work Plan that has been prepared by the village government is changed following the direction of the Village Minister Regulation related to the Village Fund Priority Program. The Village Minister's Regulation on Priorities for the Use of Village Funds is also considered to limit the village government's capacity to develop village planning, as 74,000 villages in Indonesia have different priorities according to local characteristics, natural resources and culture. At least the Village Ministry can be more consistent in this case so that the village government has no difficulty in planning. This delay is one of the factors. The villages make poor planning documents.

In addition, the problem of the often changing rules that make the village government difficult to understand, such as Government Regulation Number 60 of 2014 on Village Funds sourced from the State Budget of Revenue and Expenditure in 2015 changed again with Government Regulation Number 22 of 2015 on about Amendment to Government Regulation Number 60 of 2014 concerning Village Funds derived from the State Revenue and Expenditure Budget which is then revised again in 2016 with Government Regulation Number 8 of 2016 on the Second Amendment to Government Regulation Number 60 Year 2014 on Village Funds that come from State budget. Changes in government regulations are quite confusing to the Village Government.

\section{Supervision of District Government}

In the Minister of Home Affairs Regulation Number 113 of 2014 on Village Financial Management explained that "District/municipality governments shall develop and oversee the implementation of village financial management". 16

The District Government has the authority to oversee the implementation of village financial management, through the regent with its supervisory form that is issuing a number of rules and policies related to the financial management of the Village, other than that the Regional Device Work Unit in this Village Community Empowerment Department as part of the village government in managing resources to achieve the goals, and as the main booth for the village administration process. This is in accordance with the interview result of the Researcher with the Head of Village Community Empowerment Department Mr. Fadli T. Usup on March 10, 2018. "The Village Community Empowerment Office always guards the village government from the planning process to the implementation process, the form of supervision carried out by monitoring the villages from planning to implementation, as well as opening the public complaints form as a form of supervision". ${ }^{17}$

Village Community Empowerment Office has the duty to always coordinate with the village government related to the planning that will be made up to the implementation, this is to facilitate the village community in managing the existing budget and can minimize the deviations that occur at the level of village government.

In addition to the Village Community Empowerment Office, the district Inspectorate as the Government's Internal Supervisory Authority also has the authority to oversee the village administration in terms of village financial management. In accordance with Law Number 6 of 2014 on Village explained that the district government in this case inspectorate role oversees the management of village finances and utilization of village assets. In addition, the

\footnotetext{
${ }^{15}$ Article 17. Government Regulation No. 8 of 2016 concerning village funds sourced from the State Revenue and Expenditure Budget

${ }^{16}$ Article 44 paragraph 2. Regulation of the Minister of Home Affairs Number 113 Year 2014 on Management of Village Finance

${ }^{17}$ Fadli T. Usup. Head of Bolaang Mongondow Utara Village Community Empowerment Office. March 10, 2018
} 
inspectorate also plays a role in guiding and supervising the implementation of village governance. In a joint research interview with Secretary Inspectorate of Bolaang County Mongondow North, "Form of supervision conducted by the district inspector is monitoring conducted 2 times in one year, and audit the realization accountability report of the implementation by the villages. To monitor the implementation of the activities, the district inspectorate goes down together with the Financial Supervisory Agency". ${ }^{18}$

In terms of financial management of the Village there are three District Working Units that fought to provide guidance and supervision of the Village Community Empowerment, District Inspectorate and Financial Supervisory Board. These three Regional Devices are guarding the management of village finances.

\section{Human Resources of Village Government}

Since the birth of Law Number 6 Year 2014 on the Village, the Availability of Human Resources who have sufficient education or at least high school is very limited, even if there are almost no human resources who settled in the village, they are more opting out of the region to the tech industry area to get a job that is considered sufficient to meet the needs of life and continue his career and profession. If there is a resident in the village, Human Resources prefer to be honorary workers working in the field of education or government agencies.

We need to know that the characteristic of social backwardness is the nature of traditional societies associated with primordial values that in itself do want to maintain permanently what has been there. Thus doesn't provide enough opportunities for the changes and the growth of renewal forces in society. A condition of backwardness that reinforces this is the low level of education system and quality. ${ }^{19}$

Based on the results of the researchers' interviews along with the Expert Advisory Team of Bolaang Mongondow North Village Mr. Hamri Mokoagow on March 15, 2018, "The influence of human resources in the village in improving village governance is very large, so far the human resource factor is still a constraint in the management of village finances in Bolaang Mongondow North district. because of the many obstacles in the implementation and management so that this needs to continue to be improved together through the national evaluation Ministry of Village until the Village Community Empowerment Department of the province of Indonesia and the team of experts assistance village throughout Indonesia". ${ }^{20}$

The problem of Human Resources in the Village Government which is the obstacle factor in the implementation of governance of financial management in the village becomes a fundamental problem in handling it needs cooperation from the level of central government, local government and team of professionals. If this is left then every year the government will always meet the same problem point on the financial management of the Village from the planning stage to the responsibility.

Based on the results of interviews Researchers together with Mr. Samuel Pontoh employee Village Community Empowerment Service District Boaang Mongondow North On March 7, 2018, "Technical problems that are often encountered every year in the village that is related to the administrative process that must be fulfilled by the village government for the disbursement stage Funds such as in the preparation of Budget Revenue and Expenditure Budget, each village always finds difficulties in making this document, and which is the reason that the availability of Human Resources in the Village is very lacking". ${ }^{21}$

The difficulty of the village government in preparing the Budget and Expenditure Budget as the administrative requirement in budget disbursement is a problem that is often faced by the village government. So this causes the disintegration in the disbursement of Funds in each village that impact on the realization of the implementation of programs that aren't maximal activity.

\footnotetext{
${ }^{18}$ Secretary of Inspectorate of North Bolaang Mongondow district.

${ }^{19}$ Subandi M.M. Ekonomi Pembangunan. Alfabeta. 2016. p 11

${ }^{20}$ Hamri Mokoagow. Expert Advisory Team of Bolaang Mongondow Utara Village Village. March 7, 2018

${ }^{21}$ Samuel Pontoh. Staff of the Village Community Empowerment Service of Bolaang Mongondow North District. On March 7, 2018
} 


\section{Conclusions:-}

The consistency of planning and implementation of village finance management in Bolaang Mongondow North Regency is good enough. Big Bangs The villages in Bolaang Mongondow North District have performed the financial management stages well, but there are still some villages with poor financial management, the problem is technical problems such as inadequate timing of the Village government in carrying out planning food so that the impact not maximal achievement of the realization of its implementation.

The inhibiting factor in the management of village finances in Bolaang Mongondow North Regency is the problem of regulation at the center of the Center that is often changing and always the emergence of new rules that the timing of the regulation is not adjusted so that again complicate the village government, in addition regulation from the district government that became derived from the rules legislation related to village financial management that should facilitate the village government in managing village finances to date there are still three (3) rules that have not been fully made by the District Government and the problem of availability of Human Resources from the village government which is still very lack in the villages which is in the district of Bolaang Mongondow North which gives a big influence.

\section{References:-}

1. Sjafrizal. 2017. Perencanaan Pembangunan Daerah dalam era Otonomi. Rajawali Pres: Jakarta.

2. Soerjono Soekanto. 2015. Pengantar Penelitian Hukum. Rajagrafindo Persada : Jakarta.

3. Subandi M.M. 2016. Ekonomi Pembangunan. Alfabeta : Jakarta.

4. Tim Penyusun Polici Paper. 2015. Sinergi Perencanaan dan Penganggaran. KPPN : Jakarta.

5. BPK.Sinergi Pengawasan Untuk Percepatan Pembangunan Yang Akuntabel. Warta Pengawasan. Vol XXIV No 2. 2017.

6. Law Number 6 Year 2014 About Villages.

7. Minister of Home Affairs Regulation No. 113 of 2014 on Village Financial Management.

8. Regulation of the Minister of Finance No. 49 of 2016 on Procedure of Appropriation, Distribution, Budgeting, Monitoring and Evaluation of Village Funds.

9. Government Regulation Number 8 Year 2016 on Village Funds. 